\title{
Growth Limiting Nutrient(s) and Their Effects on the Yield and Nutrient Uptake of Chickpea (Cicer arietinum L.) in Nitisols, Southern Ethiopia
}

\author{
Tsegaye Neway Abebe ${ }^{1^{*}} \quad$ Sheleme Beyene $^{2}$ \\ 1. Ethiopia Construction Design and Supervision Works Corporation, Addis Ababa, Ethiopia PO box Addis \\ Ababa \\ 2. Department of Plant and Horticultural Science, College of Agriculture, Hawassa University, P. O. Box 5,
} Hawassa, Ethiopia

\begin{abstract}
Field experimentation on crops grown in soils with multiple nutrient limiting situations is a challenge in terms of cost and time. Soil testing programs are evolving towards more realistic decision support systems for nutrient recommendations. In order to identify the most limiting nutrient(s) and evaluate the effects of their applications on yield and nutrient uptake of chickpea (Cicer arietinum L.) on soil samples collected from Nitisols of wolaita zone. A systematic approach was used to determine the availability of nutrients in the test soils, the sorption capacities and greenhouse study was conducted to evaluate crop responses to nutrients' additions. The soil chemical analysis revealed that the amounts of total $\mathrm{N}$, available $\mathrm{P}, \mathrm{S}, \mathrm{Zn}$ and $\mathrm{Cu}$ were deficient and less than three times the critical value in Nitisols. $\mathrm{P}, \mathrm{S}, \mathrm{Zn}$ and $\mathrm{Cu}$ were selected to conduct the sorption experiment. The results of the sorption experiment nutrient elements to be added to the optimum treatment were: P: 190, S: 37, $\mathrm{Zn}: 11$ and $\mathrm{Cu}$ : $13 \mathrm{mg}$ per $\mathrm{kg}$ soil. Soil showed a relatively high $\mathrm{P}, \mathrm{Zn}$ and $\mathrm{Cu}$ sorption value. The highest relative biomass yield of $53 \%$ and grain yield of $32 \%$ were obtained from optimum treatment. Significant increase of N, P, S, Zn and Cu content in shoot and grain emphasized the superiority of optimum treatment. $\mathrm{P}, \mathrm{S}, \mathrm{Zn}$ and $\mathrm{Cu}$ in the soil are found to be highly limiting nutrients to support chickpea growth. Therefore, external supplies of $\mathrm{P}, \mathrm{S}, \mathrm{Zn}$ and $\mathrm{Cu}$ fertilizers could be recommended for improving production of chickpea in the study area.
\end{abstract}

Keywords: Systematic Approach, Optimum Treatment, Grain yield, Biological yield, Nutrient Content

DOI: $10.7176 / \mathrm{JEES} / 11-12-02$

Publication date: December $31^{\text {st }} 2021$

\section{Introduction}

In Ethiopia, poverty and malnutrition are attributable to the mismanagement of the soil, water and plant resources which are threatening the life and livelihood of millions. This challenge will continue to exist with time due to population increases and the needs become increasingly complex. Reversing this trend in Ethiopia lies in the enhancement of sustainable development of the agricultural sector, which is a function of several biotic and abiotic resources. Sustainable agricultural productivity, in turn, has partly its origin in plants that grow on soils to produce components that are directly consumed by human beings or livestock that significantly contribute to the satisfaction of human needs by producing quantity and quality products. The implication is that the overall productivity and sustainability of a given agricultural sector is a function of fertile and productive soils.

Soil fertility depletion is the root cause for declining per capita food production in the Sub-Saharan African countries in general and in Ethiopia in particular (Sanchez et al., 1997). In the past ten years, much attention in Sub-Saharan Africa (SSA) has been focused on the quantification and estimation of nutrients that enter and leave agricultural systems. The balance between these nutrient inputs and outputs shows whether the agricultural system is a net gainer or a net loser of soil fertility. Nitrogen $(\mathrm{N})$, Phosphorus (P) and Potassium (K) balances for agricultural land use systems in Africa countries revealed a downward trend (FAO, 2003). Moreover, the densely populated and hilly countries in the Rift Valley area (Kenya, Ethiopia, Rwanda and Malawi) showed the most negative values because of a high ratio of cultivated land to total arable land, relatively higher crop yields and the high soil erosion rate. According to Eyassu (2004), in the major arable areas in Kindo Koysha District of Wolaita Zone, annual $\mathrm{N}$ balances were negative both in the lowland and highland areas, whereas P balance was highly negative in the highlands and relatively better in the lowland arable areas in Kindo Koysha district of Wolaita zone.

The major plant nutrients added to the soil include mainly $\mathrm{N}$ and $\mathrm{P}$ in the form of di-ammonium phosphate (DAP) and urea fertilizers. Limited attention has been given to other macronutrients and micronutrients in Ethiopia. However, balanced nutrition is an essential component of nutrient management and it plays a significant role in increasing crop production and its quality. As a result of continuous introduction of new crop varieties and with the application of only some macronutrients such as $\mathrm{N}$ and $\mathrm{P}$ is expected to cause imbalance in plant nutrients, the less important nutrients will be yield limiting factors. Despite the fact that optimum plant growth and crop productivity cannot be realized without adequate and balanced soil nutrient supplies, nutrient management in crops is frequently restricted to major fertilizer nutrients: $\mathrm{N}, \mathrm{P}$, and/or $\mathrm{K}$. 
This is particularly true in low-input high-risk drought tolerant crops, like chickpea (Cicer arietinum L.), frequently grown under rainfed conditions in coarse-textured and/or low- fertility soils (Saxena, 1987). In chickpea grown under greenhouse conditions, application of $100 \mathrm{mg} \mathrm{P} \mathrm{kg}^{-1}$ resulted in increased uptake of $\mathrm{Zn}, \mathrm{Cu}, \mathrm{Fe}$ and Mn but decreased the concentration of $\mathrm{Ca}$ and $\mathrm{Mg}$ in the plant tissues (Tufemkci et al., 2005). In India, a number of studies have been conducted regarding effect of $\mathrm{S}$ on yield of leguminous crops and on average $22 \%$ increase in yield of legume crops (chickpea, pigeon pea, lentil, pea, urd bean, ground nut) has been recorded (Shrinivasarao et al., 2004; Raina and Tanawade, 2005). While in European countries, 78\% yield increase in pea (Pisum sativum) has been reported under pot experiments (Scherer et al., 2006).

Mineral nutrient deficiencies limit $\mathrm{N}$ fixation by the legume-Rhizobium symbiosis, resulting in low legume yields. Nutrient limitations to legume production result from deficiencies of not only major nutrients but also micronutrients (Bhuiyan et al., 1999). Micronutrients play important roles in increasing yield of pulses through their effects on the plant itself and on the $\mathrm{N}$ fixing symbiotic process. The deficiencies of these nutrients have been highly pronounced under multiple cropping systems due to excessive removal by crops.

Proper understanding of the nature and properties of the soils of Ethiopia and their management according to their potentials and constraints is imperative for maximization of crop production as close to the potential limits as possible (Abayneh and Brehanu, 2006). Assessment of soil fertility has considerable importance to determine the factors that limit yield and to take remedial measures.

Chickpea is a less labor-intensive crop and its production demands low external inputs compared to cereals. In Ethiopia, chickpea is widely grown across the country and serves as a multi-purpose crop (Shiferaw et al., 2007). First, it fixes atmospheric $\mathrm{N}$ in soils and thus improves soil fertility and saves fertilizer costs in subsequent crops. Second, it permits intensive and productive use of land, particularly in areas where land is scarce and the crop can be grown as a second crop using residual moisture. Third, it reduces malnutrition and improves human health especially for the poor who cannot afford livestock products. It is an excellent source of protein, fiber, complex carbohydrates, vitamins and minerals. Fourth, the growing demand in both the domestic and export markets provides a source of cash for smallholder producers. Fifth, it increases livestock productivity as the residue is rich in digestible crude protein content compared to cereals.

In order to make the best out of multiple benefits of chickpea, it is important to assess the soil fertility to improve the chickpea production in the study area. It is also important to determine nutrient imbalances through laboratory and greenhouse experiments to prevent nutrient deficiencies from impacting on crop growth and yields. Identifying the limiting soil nutrient and determining the optimal fertilizer requirement through laboratory analysis and greenhouse experiments are necessary prior to conducting field experiments (Portch and Hunter, 2002). The process allows the flexibility in this approach for repeating relatively inexpensive greenhouse experiments in case there is any need for further clarification of any detected nutrient disorders.

A study conducted in Taba sub-watershed showed that total $\mathrm{N}$, available $\mathrm{P}$ and $\mathrm{K}$ are in the low range and $\mathrm{Zn}$ and $\mathrm{Cu}$ are also lower than three times the critical value in soil (Wondimu, 2012). In order to set priorities among the different plant nutrients for future considerations in soil fertility experiments and fertilizer trials, it is crucial to identify the most limiting nutrients and the response of chickpea to their application. Thus, this study was entailed to generate basic information of soil nutrient status and soil sorbing capacities and identify the most growthlimiting nutrients in major soil types of Gununo Sub-Watersheds and determine the response of chickpea to application of the deficient nutrients,

\section{Materials and Methods \\ 2.1 Description of the Study Sites}

The study was conducted on soil samples collected from Gununo sub-watershed is located at about $430 \mathrm{~km}$ south of Addis Ababa and $23 \mathrm{~km}$ west of Sodo town. It is situated between 6051' and 6056' $\mathrm{N}$ latitude and 370 39' and $37040^{\prime}$ E longitude with altitude ranging between 1880 to 1960 m.a.s.l. The topography of the area is characterized by undulating slopes divided by $\mathrm{v}$-shaped valleys of seasonal and intermittent streams, surrounded by steep slopes. The dominant soils in the study area are Eutric Nitisols, very deep $(>30 \mathrm{~m})$, acidic in nature, and very highly degraded, mostly because of soil erosion, and crop production is very difficult. These soils originated from kaolinitic minerals which are inherently low in nitrogen and phosphorus (Waigel, 1986).

The main crops grown in the sites are cereals such as teff (Eragrostis tef), maize (Zea mays), wheat (Triticum aestivum), barley (Hordeum vulgare), pulses such as faba bean (Vicia faba), field pea (Pisum sativum), haricot bean (Phaseolus vulgaris), chickpea (Cicer arietinum), and root and tuber crops such as potato (Solanum tuberosum), sweet potato (Ipomea batatas) and enset (Ensete ventricosum).

\subsection{Soil Sampling and Sample Preparation}

Thirty random samples (0-20 cm depth) were collected from dominant homogenous arable lands following random sampling technique and a composite was made. The bulk soil samples used for pot were crushed with a wood pestle and mortar to pass through a $2 \mathrm{~mm}$ sieve and separated experiment for physico-chemical analyses. The 
portions of the samples for determinations of organic carbon and total nitrogen were further ground to pass through a $0.5 \mathrm{~mm}$ sieve.

\subsection{Soil Analysis}

Particle size analysis was carried out by the modified sedimentation hydrometer procedure (Bouyoucos, 1962). Soil $\mathrm{pH}$ was measured in the supernatant suspension of a 1:2.5 soil: water mixture by using $\mathrm{pH}$ meters. Organic carbon content of the soil was determined following the wet digestion method (Walkley and Black, 1934). Total $\mathrm{N}$ was analyzed by the Kjeldahl procedure (Bremner and Mulvaney, 1982). The available phosphorus content of the soil was analyzed using $0.5 \mathrm{M}$ sodium bicarbonate extractant at $\mathrm{pH} 8.5$ and blue color development by ascorbic acid method (Olsen and Sommers, 1982).

Exchangeable basic cations and the cation exchange capacity (CEC) of the soils were determined using the $1 M$ ammonium acetate ( $\mathrm{pH} \mathrm{7)} \mathrm{method} \mathrm{according} \mathrm{to} \mathrm{the} \mathrm{percolation} \mathrm{procedure} \mathrm{(Van} \mathrm{Reeuwijk,} \mathrm{1993).} \mathrm{The}$ exchangeable cations, $\mathrm{Ca}$ and $\mathrm{Mg}$, in the leachate were determined by Atomic Absorption Spectrophotometer, whereas $\mathrm{K}$ and $\mathrm{Na}$ were measured by flamephotometer. For CEC determination, the excess ammonium was washed with $95 \%$ ethanol, the adsorbed ammonium was exchanged for $\mathrm{Na}$ by leaching with $100 \mathrm{ml}$ of $10 \% \mathrm{NaCl}$ solution. The amount of ammonium was determined by titrating against $0.1 \mathrm{M} \mathrm{NaOH}$ after adding four drops of methyl red indicator.

Sulphate was determined by potassium dihydrogen phosphate solution as extractant (Johnson and Fixen, 1990). Available micronutrients (Fe, $\mathrm{Mn}, \mathrm{Zn}$, and $\mathrm{Cu}$ ) contents of the soils were determined by DTPA method (Lindsay and Norvell, 1978). The concentration of water-soluble boron was determined by hot water extraction (Sippola and Ervio, 1977).

\subsection{Sorption Studies}

\subsubsection{Preparation of sorption treatment solutions}

A series of 5 sorption treatment solutions were prepared by using stock solution from each nutrient source (Table 1).

Table 1: Concentrations of some essential nutrients used in sorption treatment solutions.

\begin{tabular}{ccccc}
\hline $\begin{array}{c}\text { Sorption treatment } \\
\text { solution No. }\end{array}$ & \multicolumn{4}{c}{ Concentration of elements in sorption treatment solutions $\left(\mathrm{mg} \mathrm{L}^{-1}\right)$} \\
\cline { 2 - 5 } & $\mathrm{P}$ & $\mathrm{S}$ & $\mathrm{Zn}$ & $\mathrm{Cu}$ \\
2 & 20 & 10 & 1 & 1 \\
3 & 40 & 20 & 2 & 2 \\
4 & 80 & 40 & 4 & 4 \\
5 & 160 & 80 & 8 & 8 \\
\end{tabular}

\subsubsection{Sorption of $P, S, Z n$ and $C u$}

The quantitative description of soil nutrient sorption is important for the prediction of nutrients fertilizer requirements for optimum plant growth (Fox and Kamprath, 1970). Sorption of P, S, Zn and Cu by soils plays a crucial role among all nutrients. The sorption study for $\mathrm{P}, \mathrm{S}, \mathrm{Zn}$ and $\mathrm{Cu}$ were done in bottles using 2 checks and 5 treatments in duplicates. Five gm of soil was weighed into 12 bottles. Bottle No.1 was used as the check; where only $5 \mathrm{ml}$ of distilled water was added. Five $\mathrm{ml}$ of sorption treatment solutions, 1 to 5 were added to bottles No 2 to No 6, respectively (Table 1). After the addition of sorption treatment solutions, the bottles were gently shaken to ensure complete mixing of the solution with the soil and allowed to incubate for 72 hours (Hunter, 1980). The bottles were placed in a dust-free place and allowed to air dry. After the samples were air dried, they were extracted and analyzed for available $\mathrm{P}, \mathrm{S}, \mathrm{Zn}$ and $\mathrm{Cu}$ following standard procedures as indicated in soil analysis.

A sorption curve was constructed for each element, plotting the amount of element extracted against the amount of element added. The amount of element added was equal to the concentrations of the sorption treatment solutions (Table 1). These sorption curves were used to determine the amount of elements to be added in the treatments of greenhouse experiment.

\subsection{Greenhouse Studies}

\subsubsection{Determination of optimum levels of elements}

Greenhouse experiment using chickpea as the test crop was conducted based on both soil analysis and sorption results. The amounts of nutrient elements extracted from the original soil sample were below 3 times the critical levels of the elements and the chemical fertilizers used were: Urea, TSP, $\mathrm{Na}_{2} \mathrm{SO}_{4}, \mathrm{ZnCl}_{2}$, and $\mathrm{CuCl}_{2}$ as sources of $\mathrm{N}, \mathrm{P}, \mathrm{S}, \mathrm{Zn}$ and $\mathrm{Cu}$, respectively. Then the amounts of these elements necessary to bring the levels to 3 times the critical levels were added. The critical levels considered for the nutrients were; P: 14, S: 14, Zn: 2 and Cu: $1 \mathrm{mg}$ $\mathrm{kg}^{-1}$ soil (Hunter, 1980) 
Table 2: Treatment descriptions and the amounts of elements added to the soils

Treatment No $\quad$ Description Amount of element added ( $\left.\mathrm{mg} \mathrm{kg}^{-1} \mathrm{soil}\right)$

\begin{tabular}{llc}
\hline & Check & None \\
2 & Opt. & N: 18, P: 190, S: 37, Zn: 11, Cu: 13. \\
3 & Opt. (- N) & $(-18)$ \\
4 & Opt. (- P) & $(-190)$ \\
5 & Opt. (- S) & $(-37)$ \\
6 & Opt. (- Zn) & $(-11)$ \\
7 & Opt. (- Cu) & $(-13)$ \\
\hline
\end{tabular}

Opt. = Optimum Treatment, Opt. - = Optimum Treatment without the indicated element

\subsubsection{Plant data collection and sampling}

The experiment was conducted in a greenhouse at Hawassa University. Three $\mathrm{kg}$ of soil was placed in plastic pot. The soil from each pot was spread in a thin layer on a paper sheet, measured amounts of stock nutrient were applied and the soil was mixed thoroughly before returning it to the pot. The treatments were arranged in a completely randomized design (CRD) with three replications.

Chickpea was used as test crop and six seeds were sown in each pot and thinned to 4 plants per pot at 21 days after emergence. The soils in all pots were maintained at approximately field capacity during the experimental period by watering with distilled water. Following each watering, leachates on the saucers were reapplied to the pots.

Nodulation assessment was undertaken at flowering stage (50\%) by carefully uprooting two plants randomly from each pot and the plants were separated into shoot and roots. The adhering soil was carefully washed from the roots over a metal sieve. The nodules from each plant were picked and spread on the sieve to drain water from their surface. Nodules were counted and their average was taken as number of nodule per plant. Thereafter, the nodules were oven-dried at $70{ }^{\circ} \mathrm{C}$ for 48 hours and nodule dry weights were determined.

At physiological maturity (90 days), plant height was recorded and the above ground parts of the plants were harvested and fresh weights were measured. Contaminants were removed from the above ground parts by first dipping samples in $0.001 \mathrm{M} \mathrm{HCl}$, and then washing with tap water and finally rinsed with distilled water. The above ground parts were dried in an oven at $70{ }^{\circ} \mathrm{C}$ to constant weight and shoot dry weights were measured. The dry plant material was finely ground using stainless steel grinder to pass through $1 \mathrm{~mm}$ sieve and preserved for analysis.

\subsection{Plant Analysis}

Nitrogen in the plant material was analyzed by modified Kjeldahl wet oxidation procedure that involves digestion of the sample to convert organic $\mathrm{N}$ to $\mathrm{NH}_{4}{ }^{+}-\mathrm{N}$ and determination of $\mathrm{NH}_{4}{ }^{+}-\mathrm{N}$ in the digest (Nelson and Sommers, 1973). One gram of plant material (dried at $450^{\circ} \mathrm{C}$ for 4 hours) was calcinated in a muffle furnace by placing into porcelain crucibles. The calcinated plant material was dissolved in $20 \mathrm{ml}$ of $20 \%$ nitric acid and filtered for the determination of nutrient elements by filling the flask to $100 \mathrm{ml}$ mark with distilled water. $\mathrm{Ca}, \mathrm{Mg}, \mathrm{Mn}, \mathrm{Fe}, \mathrm{Zn}$ and $\mathrm{Cu}$ in the filtrate were determined by Atomic Absorption Spectrophotometer (AAS), whereas K was measured by flame photometer. $\mathrm{P}$ determination was carried out in the digest aliquot obtained through calcinations. The $\mathrm{P}$ in the solution was determined colorimetrically by using molybdate and metavanadate for color development (Wolf, 1982). Sulfur was determined by magnesium nitrate dry ashing method as described by Wolf (1982). Boron in plant samples was measured colorimetrically using Azomethine-H by dry ashing with $\mathrm{CaO}$ (Sippola and Ervio, 1977).

\subsection{Statistical Analysis}

Statistical analysis was carried out on number of nodules, nodule dry weight, plant height, biological yield, grain yield, nutrient concentration and uptake using statistical analysis software (SAS, 1997 version 9.0). Mean separation was done using least significant difference (LSD) at $0.05 \mathrm{P}$ level and correlation analysis was also conducted following Pearson correlation coefficients.

\section{Results and Discussion}

\subsection{Major Physico-chemical characteristics of the experimental soils}

The composite soil sample which was collected from the Gununo area before sorption study and greenhouse planting was analyzed for some of physical and chemical properties: texture, $\mathrm{pH}, \mathrm{EC}, \mathrm{OC}$, Total N, CEC, available $\mathrm{P}$, exchangeable bases and micronutrients (Table 1). Analytical results indicated that the soil texture of Gununo Nitisols was clay loam. Soil texture is a fundamental physical property of a soil and it is closely related to the water-holding capacity of the soils, since loams and clays hold more water than that of sandy soils (Brady, 2000). Thus, the soil of the study area has good water holding capacity, which creates a good growing media for chickpea. 
The soil $\mathrm{pH}$ of the experimental soil is slightly acidic with $\mathrm{pH}$ values of 5.9 and thus within the range of optimum soil $\mathrm{pH}$ for crop production (Havlin et al., 1999). According to Havlin et al, (1999) soils are classified depending on their total nitrogen content $(\%)$, as very low $(<0.1)$, low (0.1-0.15) medium (0.15-0.25), and high $(>0.25)$. Thus, the experimental soil has low $(0.15 \%)$ nitrogen content. According to Landon (1991) the classifies for the organic carbon content of soils are: low $(<4)$, medium $(4-10)$, high $(>10)$. The Experimental soil organic matter content is $1.26 \%$ and this is considered to be low. The results are in accordance with the findings of Wakene and Heluf (2003), and Wondwosen (2008) who reported that intensive and continuous cultivation forced oxidation of organic carbon and thus resulted in reduction of Total $\mathrm{N}$.

The cation exchange capacity (CEC) of the soils are medium in the soil, According to Landon (1991), CEC values are rated $<5$ as very low, $5-15$ as low; $15-25$ as medium, $25-40$ as high and $>40$ as very high. According to Brady and Weil (2002), CEC depends on the nature and amount of colloidal particles. The exchange complex of the soils is dominated by $\mathrm{Ca}$ followed by $\mathrm{Mg}, \mathrm{K}$ and $\mathrm{Na}$ (Table 3). According to Havlin et al. (1999), the dominance of $\mathrm{Ca}$ followed by $\mathrm{Mg}, \mathrm{K}$, and $\mathrm{Na}$ in the exchange site of soils is favorable for crop production. This result is in agreement with the findings of Wondwosen (2008) on Alfisols and Ultisols in Kindo Koye and Delbo area, Southern Ethiopia and Wakene (2001) on Alfisols around Bako area, Ethiopia.

Available phosphorus content was $3.5 \mathrm{mg}$ per $\mathrm{kg}$ soil and this is considered to be low. The range of Olsen $\mathrm{P}$ ratings are very low $(<3)$, low (4-7) medium (8-11), and high $(>12)$ according to Havlin et al. (1999). According to Tekalign and Haque, (1991), Olsen soil tests for plant available P was recommended for all types of Ethiopian soils. The low availability of $\mathrm{P}$ in the soil may be due to the inherent $\mathrm{P}$ deficiency of the soils and the $\mathrm{P}$ fixation with $\mathrm{Fe}$ and $\mathrm{Al}$, as these soil was slightly acidic in reaction (Table 3 ). Therefore, the soils is deficient in available $\mathrm{P}$ and require application of $\mathrm{P}$ fertilizer for optimum crop production.

The available sulfur content was $9.5 \mathrm{mg} / \mathrm{kg}$ soil. According to Havlin et al. (1999), the available S contents of the soils could be considered to be adequate for most crop production, although the value in the soil is below three times the critical value (42 $\mathrm{mg} \mathrm{S}$ per $\mathrm{kg}$ soil). Adsorbed sulphate is an important fraction in highly weathered soils in regions of high rainfall containing large amounts of $\mathrm{Al} / \mathrm{Fe}$ oxides. Adsorbed sulphate in highly weathered soils can contribute significantly to the $S$ needs of plants because it is usually readily available (Havlin et al., 1999).

Table 3: Physico-chemical properties and available nutrients status of experimental soil

\begin{tabular}{|c|c|}
\hline Soil property & Value \\
\hline Soil Taxonomy & Nitisols \\
\hline $\mathrm{pH}(1: 2.5)$ & 5.9 \\
\hline Organic carbon $(\%)$ & 1.26 \\
\hline Total N (\%) & 0.15 \\
\hline Sand $(\%)$ & 31 \\
\hline Silt (\%) & 36 \\
\hline Clay $(\%)$ & 33 \\
\hline Textural Class & Clay Loam \\
\hline $\mathrm{Na}\left[\operatorname{cmol}(+) \mathrm{kg}^{-1}\right.$ soil $]$ & 0.12 \\
\hline $\mathrm{K}\left[\mathrm{cmol}(+) \mathrm{kg}^{-1}\right.$ soil $]$ & 1.39 \\
\hline $\mathrm{Ca}\left[\mathrm{cmol}(+) \mathrm{kg}^{-1}\right.$ soil $]$ & 9.06 \\
\hline $\operatorname{Mg}\left[\operatorname{cmol}(+) \mathrm{kg}^{-1}\right.$ soil $]$ & 2.22 \\
\hline $\mathrm{CEC}\left[\mathrm{cmol}(+) \mathrm{kg}^{-1}\right.$ soil $]$ & 23.49 \\
\hline $\mathrm{K}: \mathrm{Mg}$ & 0.63 \\
\hline $\mathrm{Ca}: \mathrm{Mg}$ & 4.1 \\
\hline Av. P (mg kg-1 soil) & 3.35 \\
\hline Av. K (mg kg-1 soil) & 545 \\
\hline Av. S (mg kg-1 soil) & 9.5 \\
\hline Av. Fe (mg kg ${ }^{-1}$ soil $)$ & 27.2 \\
\hline Av. Mn (mg kg-1 soil) & 7.7 \\
\hline Av. Zn (mg kg ${ }^{-1}$ soil) & 1.3 \\
\hline Av. $\mathrm{Cu}\left(\mathrm{mg} \mathrm{kg}^{-1}\right.$ soil $)$ & 0.11 \\
\hline Av. B (mg kg-1 soil $)$ & 1.10 \\
\hline
\end{tabular}

The concentration of available micronutrients in the soil from highest to lowest concentration is $\mathrm{Fe}>\mathrm{Mn}>$

$\mathrm{Zn}>\mathrm{Cu}$. The amount of $\mathrm{Fe}, \mathrm{Mn}, \mathrm{Zn}$ and $\mathrm{Cu}$ in $\mathrm{mg} \mathrm{kg}^{-1}$ in the soil is 27.2, 7.7, 1.3 and 0.11 , respectively, (Table 3). The micronutrient content of soils is influenced by several factors among which soil organic matter content, soil reaction and clay content are the major ones (Fisseha, 1992). According to critical values of available micronutrients set by Havlin et al. (1999) are 4.5, 1.0, 1.0 and $0.6 \mathrm{mg} \mathrm{kg}^{-1}$ for Fe, $\mathrm{Mn}, \mathrm{Zn}$, and $\mathrm{Cu}$, respectively. The amount of $\mathrm{Mn}$ and $\mathrm{Fe}$ in the soil is above the critical limits and crops may not have a deficiency of these elements. However, the amount of $\mathrm{Zn}$ and $\mathrm{Cu}$ in the soil is below the critical value. Zinc and Copper are one of the yield limiting nutrients in experimental soil. 


\subsection{Sorption Characteristics of the experimental soils}

Sorption curves for $\mathrm{P}, \mathrm{S}, \mathrm{Zn}$ and $\mathrm{Cu}$ were constructed for the determination of amounts of elements to be added to obtain extractable amounts equal to three times the critical value (the optimum level). The value for each element was obtained from the graph and converted to the respective fertilizer equivalents (Figure 1-4).

The amounts of $\mathrm{P}, \mathrm{S}, \mathrm{Zn}$ and $\mathrm{Cu}$ retention, as percent of applied nutrients, in the soil were 62-84, 3-67, 53-65 and $81-87 \%$, respectively. The sorption results indicated that $\mathrm{P}, \mathrm{Zn}$ and $\mathrm{Cu}$ were highly fixed by the soil. This could be due to the weathering stage of the soils. Based on the sorption curve the nutrient elements to be added to the optimum treatment were: P: $190, \mathrm{~S}: 37, \mathrm{Zn}: 11$ and $\mathrm{Cu}: 13 \mathrm{mg} \mathrm{kg}^{-1}$ soil.

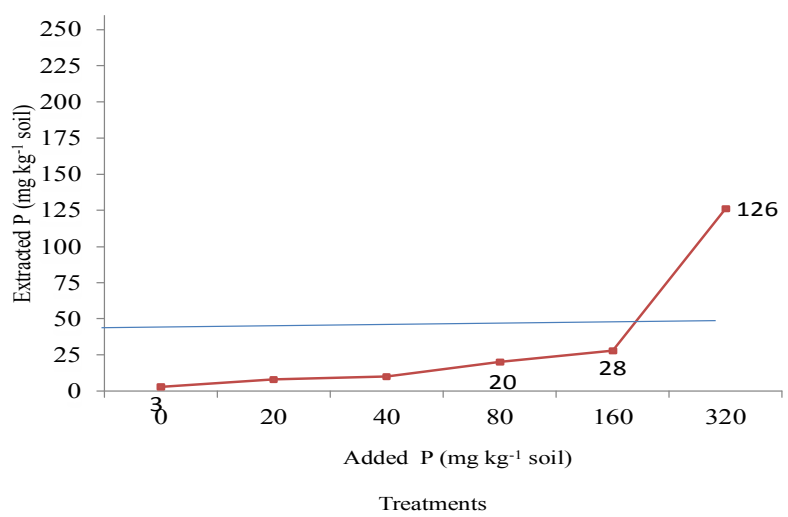

Figure 1: Phosphorus sorption of the experimental soils

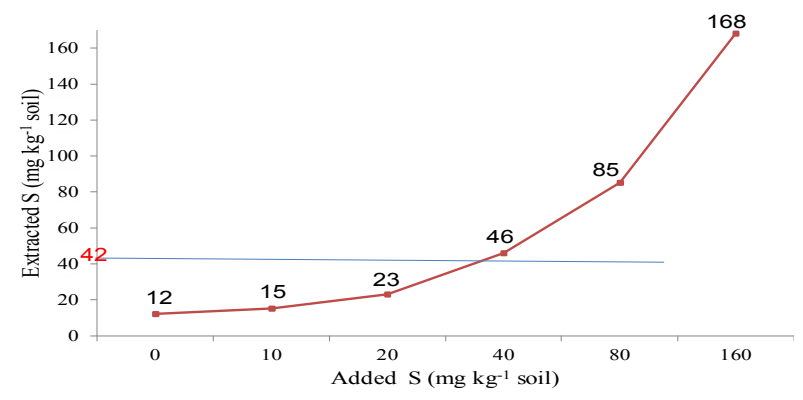

Treatments

Figure 2: Sulfur sorption of the experimental soils

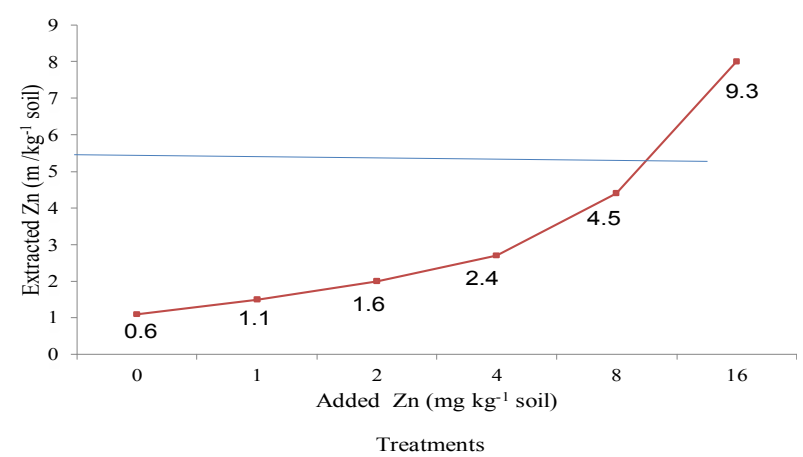

Figure 3: Zinc sorption of the experimental soils 


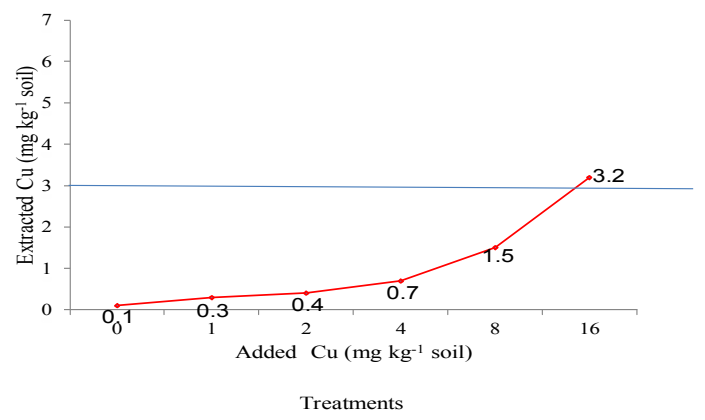

Figure 4 Copper sorption of the experimental soils

The clay mineralogy, presence of oxides and hydroxides of $\mathrm{Fe}$ and $\mathrm{Al}$ seem to be the dominant factors affecting $\mathrm{P}, \mathrm{Zn}$ and $\mathrm{Cu}$ sorption. The mechanism of phosphate zinc and copper adsorption is considered to be mainly through replacement of hydroxyl ions on crystal lattice, and hydrated iron and aluminum by phosphate, zinc and copper ions. High sorption of phosphate by amorphous materials, and oxides and hydroxides of iron and aluminum have been reported by several investigators (Fitter, 1974 and Sahlemedhin and Ahmed, 1983). The P adsorption capacity by clay minerals depends, among other factors, on the proportion of surface area occupied by edge faces. Accordingly, kaolinite absorbs more P per unit surface area than 2:1 clay minerals (Havlin et al., 1999).

The sorption result showed that $\mathrm{S}$ was fixed by the soil in medium amount. This may be due to $\mathrm{S}$ adsorbed in oxides and hydroxides of iron and aluminum and clay minerals. According to Mengel and Kirkby (1987), sulphate like phosphate is adsorbed in sesquioxides and clay minerals, although the binding strength for sulphate is not as strong as that for phosphate.

\subsection{Pot Experiment}

\subsubsection{Treatment effects on number of nodules per plant and nodule dry weight}

Fertilizer treatments had a highly significant $(\mathrm{P} \leq 0.01)$ effect on number of nodules per plant $(\mathrm{NNPP})$ and nodule dry weight (NDW). Higher NNPP, 10.3, was obtained from optimum treatments as compared to others. Similarly, the highest NDW was recorded in the optimum treatment in the soil (Table 4). This might be due to the adequate supply of nutrients, which possibly promoted the formation of lateral and fibrous root growth (Havlin et al., 2007). The increased root growth creates higher surface area (infection site) for the bacteria to form relatively higher number of nodules. Majid et al. (2009) also found increasing nodules per plant with increased phosphorus application.

Omission of $\mathrm{N}$ fertilizer did not differ from the optimum treatment in terms of NNPP. Low levels of $\mathrm{N}$ fertilizer supply as starter-N increased nodulation and total amount of nitrogen derived from $\mathrm{N}_{2}$ fixation (George et al., 1992). On the other hand, phosphorus-omitted treatment showed lower NNPP and NDW compared to all others. This might be due to the influence of $\mathrm{P}$ on root growth, photosynthesis, translocation of sugars, and other such functions which directly or indirectly influence N-fixation by legume plants.

Phosphorus fertilization enhanced number of nodules and nodule dry mass, as well as greater $\mathrm{N}_{2}$-fixation ability per plant (Sessitsch et al., 2002). Shu-Jie et al. (2007) also reported that application of P increased $\mathrm{N}$ concentrations in grain and root, and total $\mathrm{N}$ uptake. The omission of $\mathrm{Zn}$ showed lower NDW as compared to optimum treatment (Table 4), indicating that low levels of these nutrients affect root nodulation and the ability to fix enough atmospheric $\mathrm{N}$ to meet the $\mathrm{N}_{2}$ needs of the plants. Misra et al. (2002) reported an increase of $55 \%$ in root nodulation and $26 \%$ in $\mathrm{N}$ content of nodules with application of $20 \mathrm{mg} \mathrm{Zn} \mathrm{kg}{ }^{-1}$ soil.

Number of nodules per plant was positively and highly significantly $(\mathrm{P} \leq 0.001)$ correlated with nodule dry weight, uptake and concentrations of $\mathrm{P}$, and also significantly $(\mathrm{P} \leq 0.01)$ with dry matter. Similarly nodule dry weight was also positively and very highly $(\mathrm{P} \leq 0.001)$ correlated with number of nodules, dry matter, uptake and concentration of $\mathrm{P}$ in both soils (Appendix Table 1 and 2).

\subsubsection{Plant height and dry matter yield}

Plant height was significantly $(\mathrm{P} \leq 0.05)$ influenced by fertilizer treatments in the soil. The maximum mean plant heights were obtained from the optimum nutrient supply $\mathrm{S}$ - and $\mathrm{Cu}$-omitted treatments in the soil. (Tables 4). Significantly $(\mathrm{P} \leq 0.05)$ lower plant heights were recorded in control and $\mathrm{P}$-omitted treatments as compared to all the others, indicating that plant height was mainly affected by omission of $P$. These could be attributed to the pivotal role that $\mathrm{P}$ plays in early root growth and the formation of lateral fibrous and healthy roots. 
Table 4: Number of nodules, nodule dry weight, plant height and biomass yield of chickpea as influenced by treatments

\begin{tabular}{|c|c|c|c|c|c|c|}
\hline & \multicolumn{2}{|c|}{ At flowering (50 days) } & \multicolumn{3}{|c|}{ At maturity stage (90 days) } & \multirow[b]{2}{*}{$\begin{array}{l}\text { Grain yield } \\
\text { (g/pot) }\end{array}$} \\
\hline Treatment & NN PP & $\begin{array}{l}\text { NDW } \\
\left.\text { (g plant }^{-1}\right)\end{array}$ & $\begin{array}{l}\text { Plant } \\
\text { (cm) }\end{array}$ & height & $\begin{array}{l}\text { DMY } \\
\left(\text { g pot }^{-1}\right)\end{array}$ & \\
\hline Control & $9^{c}$ & $0.012^{\mathrm{c}}$ & $29.8^{c}$ & & $2.21^{\mathrm{d}}$ & $1.78^{\mathrm{e}}$ \\
\hline Optimum & $27^{\mathrm{a}}$ & $0.071^{\mathrm{a}}$ & $40.4^{\mathrm{a}}$ & & $4.73^{\mathrm{a}}$ & $2.62^{\mathrm{a}}$ \\
\hline Opt.-N & $24^{\mathrm{a}}$ & $0.035^{\mathrm{b}}$ & $35.2^{\mathrm{abc}}$ & & $4.32^{\mathrm{ab}}$ & $2.50^{\mathrm{ab}}$ \\
\hline Opt.-P & $10^{\mathrm{bc}}$ & $0.021^{\mathrm{c}}$ & $32.2^{\mathrm{bc}}$ & & $2.26^{\mathrm{d}}$ & $2.04^{\mathrm{de}}$ \\
\hline Opt.-S & $22^{\mathrm{a}}$ & $0.074^{\mathrm{a}}$ & $38.4^{\mathrm{a}}$ & & $3.78^{\mathrm{c}}$ & $2.15^{\mathrm{cd}}$ \\
\hline Opt.-Zn & $20^{\mathrm{a}}$ & $0.053^{\mathrm{ab}}$ & $37.4^{\mathrm{ab}}$ & & $4.18^{\mathrm{bc}}$ & $2.22^{\mathrm{bcd}}$ \\
\hline Opt.-Cu & $20^{\mathrm{a}}$ & $0.063^{\mathrm{a}}$ & $40.1^{\mathrm{a}}$ & & $4.29^{\mathrm{b}}$ & $2.46^{\mathrm{abc}}$ \\
\hline LSD (0.05) & 10.9 & 0.03 & 6.1 & & 0.41 & 0.33 \\
\hline CV $(\%)$ & 33.1 & 31.7 & 9.6 & & 6.36 & 8.37 \\
\hline
\end{tabular}

Values followed by the same letter(s) within a column are not significantly different at $\mathrm{P}<0.05, \mathrm{NNPP}=$ number of nodules per plant, NDW = nodule dry weight, and DMY = dry matter yield

Dry matter yield of chickpea was highly $(\mathrm{P} \leq 0.001)$ influenced by the treatments in the soil. The highest dry matter yields were obtained from the optimum treatments. The reductions in dry matter yields were 53.3, 8.7, 52.2, $20.1,11.6$ and $9.3 \%$ in the control, omission of $\mathrm{P}, \mathrm{S}, \mathrm{Zn}$ and $\mathrm{Cu}$ in the soil, respectively as compared to optimum treatment. Thus, $\mathrm{P}, \mathrm{S}, \mathrm{Zn}$ and $\mathrm{Cu}$ in the soil were limiting nutrients to support good crop growth. This is attributed to the low levels of OC, available $\mathrm{P}, \mathrm{S}, \mathrm{Zn}$, and $\mathrm{Cu}$ in the soils (Table 3 ) although the low total $\mathrm{N}$ was compensated by $\mathrm{N}$ fixing capacity of the test crop.

Most soils in the south central Rift Valley and Wolaita area are highly responsive to commercial fertilizers, especially P fertilizers (Sheleme et al., 2001). Ali et al. (2002) also reported that nutrient deficiencies cause yield losses of varying magnitude in chickpea, e.g., around $10 \%$ due to sub-optimal nodulation and hence nitrogen deficiency, $29-45 \%$ due to phosphorus, and $16-30 \%$ due to sulphur. The results are in agreement with the findings of Srinivasarao et al. (2006), who found that omission of optimum nutrients (N, P, S, and Zn) led to reduction of shoot biomass of urdbean and mungbean by $32 \%$ compared to untreated control under pot experiment. Similar results have also been reported by Ali et al. (2002), who found the yield losses due to deficiencies of $\mathrm{N}, \mathrm{P}$ and $\mathrm{S}$ up to 10, 29-45 and 16-30\%, respectively, in chickpea. Lifang et al. (2000) also reported that omission of N, P and K reduced dry matter yield by $56.4,63.9$ and $23.3 \%$, respectively. Nagendra et al. (2007) found that omission of $\mathrm{P}, \mathrm{K}$ and $\mathrm{Zn}$ in greenhouse experiments resulted in relative yields reduction by 66,75 and $75 \%$, respectively compared to the optimum treatment. As suggested by Ali et al. (2004), there is a high requirement of phosphorus by legumes as $\mathrm{P}$ affects growth of the host plant, and growth and function of the nodules. Additionally, Zinc fertilization to the soil, had a significant effect on chickpea plant height, biological yield, Zn concentration, and protein content (Khorgamy et al., 2009).

Dry matter yield of chickpea was positively and significantly $(\mathrm{P} \leq 0.001)$ correlated with nodule dry weight, uptake and concentrations of $\mathrm{N}$ and $\mathrm{P}$ and also significantly $(\mathrm{P} \leq 0.01)$ with number of nodules, plant height, grain yield and concentrations of $\mathrm{Mn}, \mathrm{Zn}$ and $\mathrm{Cu}$ in plants grown in the soil.

Fertilizer application showed highly significant $(\mathrm{p} \leq 0.001)$ influence in grain yield. The highest grain yield was obtained from optimum treatment, whereas the lowest grain yields were recorded from the control, P-S- and $\mathrm{Zn}$ - omitted treatments which were significantly inferior to all other treatments (Table 4). The optimum nutrient treatment increased grain yield by $32 \%$ over the control treatments. The magnitude of grain yield losses due to omission of $\mathrm{P}, \mathrm{S}$ and $\mathrm{Zn}$ were $22-25,18-24$ and $15-26 \%$ respectively (Table 4). The results are in line with Ali et al. (2002) who reported that $\mathrm{P}$ and $\mathrm{S}$ deficiencies caused yield losses up to $29-45$ and $16-30 \%$ respectively, in chickpea, Hussain (2010) also reported 15\% decrease in seed yield of soybean due to omission of S application, whereas $22 \%$ yield increment chickpea was obtained due to S application (Shrinivasarao et al., 2004). 


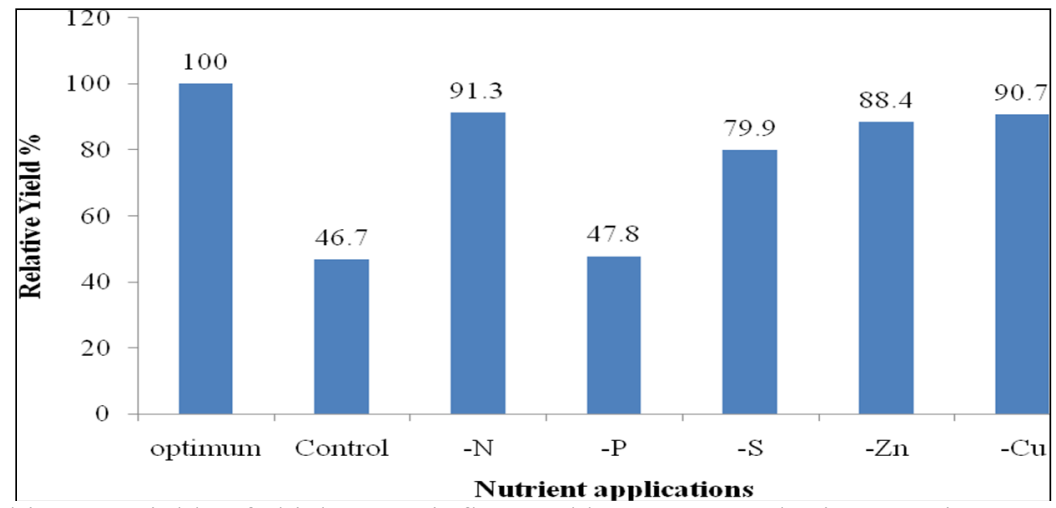

Figure 5 Relative biomass yields of chickpea as influenced by macro- and micro-nutrient application in Nitisols of Gununo under greenhouse condition

\subsection{Macronutrients concentrations and uptake}

Nitrogen concentration and uptake were significantly $(\mathrm{P} \leq 0.001)$ influenced by treatments (Appendix 1 and 2 ). Shoot and grain $\mathrm{N}$ concentrations in the plants with optimum treatment were 1.11 and $6.04 \%$ respectively in the soil; The lowest values for these parameters were obtained from the control and P-omitted treatments (Table $5 \&$ 6). Varies 66 to $85 \%$ of the $\mathrm{N}$ was found in grains indicating that grain is an important $\mathrm{N}$ sink in the plant and showing chickpea as an important source of protein. Higher $\mathrm{N}$ concentration in the grain than in stem might be due to the remobilization of large amounts of $\mathrm{N}$ from vegetative parts to pods during reproductive stage. The highest $\mathrm{N}$ content under optimum nutrient treatment could be attributed to adequate supply of starter $\mathrm{N}$ to initiate roots and infection sites and is in agreement with the finding of Srinivasarao et al. (2006), who reported 2.67\% of $\mathrm{N}$ content in shoot of urdbean and mungbean, due to supply of optimum nutrient N, P, K, S, and Zn.

Table 5: Effect of nutrient application on macronutrients concentrations by chickpea shoot

\begin{tabular}{lllllll}
\hline Treatment & $\mathrm{N}$ & $\mathrm{P}$ & $\mathrm{K}$ & $\mathrm{Ca}$ & $\mathrm{Mg}$ & $\mathrm{S}$ \\
\cline { 2 - 7 } & & \multicolumn{5}{c}{$\%$} \\
\hline Control & $0.89^{\mathrm{ab}}$ & $0.17^{\mathrm{b}}$ & 0.84 & 0.10 & 0.18 & $0.13^{\mathrm{b}}$ \\
Optimum & $1.11^{\mathrm{a}}$ & $0.35^{\mathrm{a}}$ & 0.98 & 0.09 & 0.23 & $0.39^{\mathrm{a}}$ \\
Opt.-N & $0.81^{\mathrm{b}}$ & $0.36^{\mathrm{a}}$ & 1.28 & 0.11 & 0.25 & $0.33^{\mathrm{a}}$ \\
Opt.-P & $0.54^{\mathrm{c}}$ & $0.20^{\mathrm{b}}$ & 1.15 & 0.10 & 0.18 & $0.35^{\mathrm{a}}$ \\
Opt.-S & $1.06^{\mathrm{a}}$ & $0.34^{\mathrm{a}}$ & 1.24 & 0.10 & 0.23 & $0.14^{\mathrm{b}}$ \\
Opt.-Zn & $0.99^{\mathrm{ab}}$ & $0.32^{\mathrm{a}}$ & 0.96 & 0.10 & 0.19 & $0.36^{\mathrm{a}}$ \\
Opt.-Cu & $1.02^{\mathrm{a}}$ & $0.35^{\mathrm{a}}$ & 1.22 & 0.10 & 0.22 & $0.37^{\mathrm{a}}$ \\
\hline LSD (0.05) & 0.21 & 0.06 & $\mathrm{NS}$ & $\mathrm{NS}$ & $\mathrm{NS}$ & 0.08 \\
CV (\%) & 13.1 & 12.5 & 24.4 & 25.3 & 18.3 & 16.5 \\
\hline
\end{tabular}

Values followed by the same letter(s) within a column for each treatment are not significantly different at $\mathrm{P} \leq 0.05$, NS (Not-significant)

Nitrogen concentrations in dry matter and grain of P-omitted treatments were very low (Table $5 \& 6$ ).

Phosphorus plays a key role in the symbiotic $\mathrm{N}_{2}$ fixation process by increasing the percent and amount of $\mathrm{N}$ in the harvested portion of the host legume (Marschner, 1995). Shu-Jie et al. (2007) found that P application on legumes can also increase $\mathrm{N}$ concentrations in grain and total $\mathrm{N}$ uptake. Results of the present study also confirm the dependency of biological nitrogen fixation on soil available $\mathrm{P}$ and are in line with the findings of Rehm and Schmitt (2002) who indicated $\mathrm{P}$ is an essential ingredient for rhizobium bacteria to convert atmospheric $\mathrm{N}_{2}$ into ammonium $\left(\mathrm{NH}_{4}\right)$ form useable by plants. Similarly, Ahlawat and Sharma (1996) found that phosphorus application had significant effect on $\mathrm{N}$ and $\mathrm{P}$ uptake in grain and stem of chickpea as well as on total $\mathrm{N}$ and $\mathrm{P}$ uptake. Additionally, the $\mathrm{N}$ uptake in P-omitted treatments was also very low owing to low dry matter yield obtained from this treatment (Table 5 \& 6). The low concentration of $\mathrm{N}$ in grain of $\mathrm{Zn}$-omitted treatment might be due to the influence of $\mathrm{Zn}$ in increasing the ability of roots to fix atmospheric N. Similarly, Misra et al. (2002) reported an increase of 55\% in root nodulation and $26 \%$ in $\mathrm{N}$ content of nodules with $20 \mathrm{mg} \mathrm{Zn} \mathrm{kg} \mathrm{soil}^{-1}$.

Phosphorus concentration and uptake in chickpea were significantly $(\mathrm{P} \leq 0.001)$ influenced by the treatments in the soil (Appendix 1 and 2). Shoot and grain P concentrations in optimum treatment plants were 0.35 and $0.54 \%$ in the soil and were higher than P-omitted and control treatments (Table $5 \& 6$ ). These values are above the critical limit in accordance with the ratings of Din et al. (1999), who indicated the critical P concentrations in whole shoots of chickpea ranging from 0.18 to $0.27 \%$. Olivera et al. (2004) also indicated that phosphorus application to legumes increase plant biomass including nodule biomass and shoot phosphorus content and uptake due to the increased rate of nitrogen fixation. The values of $\mathrm{P}$ uptake and concentration in the control and $\mathrm{P}$-omitted treatment were 
very low compared to the other treatments, signifying that $\mathrm{P}$ was one of the limiting nutrients in these soils. These are in line with the lower dry matter yields obtained in P-omitted treatments (Tables 4) and with the low available $\mathrm{P}$ contents of the soils (Table 3). Schulze et al. (2006) indicated that legumes generally have higher $\mathrm{P}$ requirement because the process of symbiotic nitrogen fixation consumes a lot of energy.

Similarly, Calcium concentration and uptake in grain were significantly $(\mathrm{P} \leq 0.001)$ influenced by the treatments in the soil, whereas significant differences in its concentration in shoot was obtained only in plants grown in the soil (Appendix 1 and 2). Grain $\mathrm{Ca}$ concentrations in optimum nutrient treatment were $0.08 \%$, indicating that all were below the critical range (Table 5 \& 6). Marschner (1995) indicated that the Ca content of plants varies between 0.1 and $5 \%$ of dry weight, and is usually lower than that of $\mathrm{K}$. This low Ca uptake occurs because $\mathrm{Ca}$ can be absorbed only by young root tips and the uptake of $\mathrm{Ca}$ can also be competitively depressed by the presence of other cations such as $\mathrm{K}$ and ammonium which are rapidly taken up by roots (Mengel and Kirkby, 1987).

Table 6: Effect of nutrient application on macronutrients concentrations by chickpea grain

\begin{tabular}{lllllll}
\hline Treatment & $\mathrm{N}$ & $\mathrm{P}$ & $\mathrm{K}$ & $\begin{array}{c}\mathrm{Ca} \\
\%\end{array}$ & $\mathrm{Mg}$ & $\mathrm{S}$ \\
\hline Control & $2.84^{\mathrm{d}}$ & $0.30^{\mathrm{c}}$ & $0.66^{\mathrm{c}}$ & $0.04^{\mathrm{bc}}$ & 0.11 & $0.10^{\mathrm{e}}$ \\
Optimum & $6.04^{\mathrm{a}}$ & $0.54^{\mathrm{a}}$ & $1.24^{\mathrm{a}}$ & $0.08^{\mathrm{a}}$ & 0.11 & $0.26^{\mathrm{a}}$ \\
Opt.-N & $3.80^{\mathrm{bc}}$ & $0.61^{\mathrm{a}}$ & $1.12^{\mathrm{a}}$ & $0.02^{\mathrm{d}}$ & 0.13 & $0.18^{\mathrm{bc}}$ \\
Opt.-P & $3.49^{\mathrm{cd}}$ & $0.40^{\mathrm{b}}$ & $1.18^{\mathrm{a}}$ & $0.04^{\mathrm{bc}}$ & 0.13 & $0.16^{\mathrm{cd}}$ \\
Opt.-S & $4.13^{\mathrm{bc}}$ & $0.55^{\mathrm{a}}$ & $1.24^{\mathrm{a}}$ & $0.03^{\mathrm{bcd}}$ & 0.13 & $0.12^{\mathrm{de}}$ \\
Opt.-Zn & $3.78^{\mathrm{bc}}$ & $0.56^{\mathrm{a}}$ & $1.08^{\mathrm{a}}$ & $0.03^{\mathrm{bcd}}$ & 0.12 & $0.20^{\mathrm{abc}}$ \\
Opt.-Cu & $4.40^{\mathrm{b}}$ & $0.62^{\mathrm{a}}$ & $0.86^{\mathrm{b}}$ & $0.05^{\mathrm{b}}$ & 0.13 & $0.22^{\mathrm{ab}}$ \\
\hline LSD (0.05) & 0.67 & 0.09 & 0.18 & 0.02 & $\mathrm{NS}$ & 0.05 \\
CV (\%) & 9.41 & 10.3 & 9.6 & 26.0 & 21.1 & 14.4 \\
\hline
\end{tabular}

Values followed by the same letter(s) within a column for each treatment are not significantly different at $\mathrm{P} \leq 0.05$, NS $=$ Not significant.

Sulfur concentration and uptake in shoot and grain were significantly $(\mathrm{P} \leq 0.001)$ different under various treatments in the soils. The plants with optimum nutrient treatments had respective shoot- and grain-S of 0.39 and $0.26 \%$ (Table $5 \& 6$ ). Shoot $\mathrm{S}$ concentration under all the treatments was within the critical range, whereas the concentrations of $\mathrm{S}$ in grain were below the critical range except for optimum treatments in the soil. The result showed that low uptake and concentration of $\mathrm{S}$ in shoot in the control and S-omitted treatments in the soil may be due to inadequate available $\mathrm{S}$ in soils indicating the possibility of response to $\mathrm{S}$ application, particularly by sensitive crops in the study area. This finding corroborates the available S contents of the soils (Table 3).

Table 7: Micronutrients concentrations in the shoot and grain of chickpea as influenced by treatments in the soil

Values followed by the same letter(s) within a column in the treatment are not significantly different, NS =Notsignificant.

\begin{tabular}{|c|c|c|c|c|c|c|c|c|}
\hline \multirow{3}{*}{ Treatment } & \multicolumn{2}{|c|}{$\mathrm{Fe}$} & \multicolumn{2}{|c|}{$\mathrm{Mn}$} & \multirow{2}{*}{\multicolumn{2}{|c|}{$\mathrm{Zn}$}} & \multirow{2}{*}{\multicolumn{2}{|c|}{$\mathrm{Cu}$}} \\
\hline & & & & & & & & \\
\hline & Shoot & Grain & Shoot & Grain & Shoot & Grain & Shoot & Grain \\
\hline Control & 599 & $254^{c}$ & 118 & $42^{b c}$ & $36.0^{\mathrm{b}}$ & $29.4^{\mathrm{d}}$ & $8.5^{c}$ & $10.7^{b c}$ \\
\hline Optimum & 902 & $325^{\mathrm{b}}$ & 117 & $56^{\mathrm{a}}$ & $63.3^{\mathrm{a}}$ & $53.1^{\mathrm{a}}$ & $13^{\mathrm{a}}$ & $14^{\mathrm{ab}}$ \\
\hline Opt.-N & 611 & $223^{c}$ & 121 & $31^{\mathrm{cd}}$ & $60.2^{\mathrm{a}}$ & $45.3^{\mathrm{ab}}$ & $10.8^{\mathrm{ab}}$ & $9.3^{\mathrm{c}}$ \\
\hline Opt.-P & 809 & $224^{\mathrm{c}}$ & 104 & $56^{\mathrm{a}}$ & $35.0^{\mathrm{b}}$ & $42.3^{b c}$ & $13^{\mathrm{a}}$ & $12^{\mathrm{ab}}$ \\
\hline Opt.-S & 962 & $326^{\mathrm{b}}$ & 128 & $48^{\mathrm{ab}}$ & $63.1^{\mathrm{a}}$ & $54.6^{\mathrm{a}}$ & $10.3^{\mathrm{b}}$ & $15^{\mathrm{a}}$ \\
\hline Opt.-Zn & 675 & $488^{\mathrm{a}}$ & 120 & $27^{\mathrm{d}}$ & $41.3^{b}$ & $31.6^{\mathrm{cd}}$ & $10.0^{\mathrm{b}}$ & $10.7^{b c}$ \\
\hline Opt.-Cu & 512 & $462^{\mathrm{a}}$ & 95 & $41^{\mathrm{bc}}$ & $57.0^{\mathrm{a}}$ & $48.5^{\mathrm{ab}}$ & $4.8^{\mathrm{c}}$ & $6.3^{\mathrm{d}}$ \\
\hline LSD (0.05) & NS & 40 & NS & 12.8 & 9.4 & 10.8 & 2.6 & 3.5 \\
\hline CV (\%) & 28.7 & 7.0 & 16.2 & 16.9 & 10.6 & 14.2 & 14.5 & 17.7 \\
\hline
\end{tabular}

\subsection{Micronutrient concentrations and uptake}

Iron uptake in the soils and concentration in shoot of plants was not significant (Appendix 1 and 2). The critical Fe concentration in plant is about $200 \mu \mathrm{g} \mathrm{g}^{-1}$ dry weight (Marschner, 1995), and the results showed all treatments had above the critical range for chickpea (Table 7). Relatively high concentrations of Fe in grain were observed in $\mathrm{Zn}$ - and $\mathrm{Cu}$-omitted treatments. In general, $\mathrm{Zn}$ and $\mathrm{Cu}$ application decreased $\mathrm{Fe}$ concentration, which might be due to ionic competition among these nutrients during nutrient uptake. Similarly, Asgelil et al. (2007) reported that crops grown in the soil didn't show deficiency of Fe in Ethiopia, and Zn fertilization affected accumulation of Fe and $\mathrm{Mn}$ in shoot dry matter of chickpea (Khan, 1998a). Earlier, in chickpea grown under greenhouse condition 
application of $100 \mathrm{mg} \mathrm{P} \mathrm{kg}^{-1}$ resulted in increased uptake of Fe in plants (Tufemkci et al., 2005). Islam et al. (2009) also reported that $\mathrm{P}$ and $\mathrm{S}$ application increase Fe uptake in stem by 74 and $70 \%$ respectively, over the control.

Manganese uptake and concentration also differed significantly $(\mathrm{P} \leq 0.001)$ with varying treatments in the soil (Appendix 1 and 2). The concentration of $\mathrm{Mn}$ in shoot and grain for optimum nutrient treatment were 117 and 56 $\mu \mathrm{g} \mathrm{g}^{-1}$ (Table 7). Srinivasarao et al. (2003) recorded Mn concentrations of 256-285 $\mu \mathrm{g} \mathrm{g}^{-1}$ in shoot of chickpea. Islam et al. (2009) reported that $\mathrm{P}$ application increased Mn uptake in stem of chickpea by $34 \%$ over the control. The concentration of $\mathrm{Mn}$ in grain was affected by all treatments in the soils indicating that at higher nutrient application rates other cations may also compete with $\mathrm{Mn}$ for transport across membranes. The results corroborate with Asgelil et al. (2007) who reported absence of Mn deficiency on crops grown on Vertisols of Ethiopia.

Similar to $\mathrm{Fe}$ and $\mathrm{Mn}, \mathrm{Zn}$ concentration and uptake in chickpea plants were also significantly $(\mathrm{P} \leq 0.001)$ affected by the treatments in the soil (Appendix 1 and 2). The concentration of $\mathrm{Zn}$ was higher in the soils with optimum nutrient supply and $\mathrm{N}, \mathrm{S}$ and $\mathrm{Cu}$ omitted treatments in the soils than other treatments. Zinc concentration in shoot and grain in optimum nutrient treatment was 63.3 and $53.1 \mu \mathrm{g} \mathrm{g}^{-1}$, which were above the critical levels of 20-21 $\mu \mathrm{g} \mathrm{g}^{-1}$ in shoot as indicated by Khan et al. (1998). However, the concentrations of $\mathrm{Zn}$ in grain of control, Pand $\mathrm{Zn}$-omitted treatment were lower than that of optimum treatment in the soils (Table 7), indicating the need for $\mathrm{Zn}$ application. Asgelil et al. (2007) also reported deficiency of $\mathrm{Zn}$ and $\mathrm{Cu}$ in 43 to $87 \%$ of the total plant samples from Vertisols and Nitisols of Ethiopia.

Similar to other micronutrients, the concentrations and uptake of $\mathrm{Cu}$ significantly $(\mathrm{P} \leq 0.001)$ differed due to different treatments in the soil (Appendix 1 and 2). Copper concentrations in shoot and grain in optimum nutrient treatment were 13 and $14 \mu \mathrm{g} \mathrm{g}^{-1}$ (Table 7), which were above the critical range for chickpea as per Cabrera et al. (2003) who indicated the critical levels of $\mathrm{Cu}$ ranging between 1.5 and $5.0 \mu \mathrm{g} \mathrm{g}^{-1}$ in legumes. Low uptake of $\mathrm{Cu}$ was observed in Zn-omitted treatment in the soil (Table 7).

\section{Conclusion}

Considering the laboratory analyses and sorption studies, $\mathrm{P}, \mathrm{Zn}$, and $\mathrm{Cu}$ had the highest potential in limiting yield, although there were also high probabilities of $\mathrm{S}$ in the soil to limit the yields. Nutrient deficiencies in Nitisols were in the order; $\mathrm{P}>\mathrm{S}>\mathrm{Zn}>\mathrm{N}>\mathrm{Cu}$.

Based on the results, $\mathrm{P}, \mathrm{Zn}$ and $\mathrm{Cu}$ in the soil were the most limiting nutrients to support good chickpea growth and development. These indicate that the soils of the study areas were inherently poor in $\mathrm{P}, \mathrm{Zn}$ and $\mathrm{Cu}$ contents to support good chickpea growth. Also it is likely to have response to S application in the soils. Thus, S in the soil are probably the limiting nutrients to support good crop growth. Therefore, external supplies of fertilizers containing these nutrients could be recommended to improve chickpea production in the study areas.

In general, this research work has given a general picture of available nutrient status and the extent of their deficiencies in Gununo sub-watersheds. The information generated from the present study would assist in developing highly productive, sustainable and ecologically stable land use and management strategies for chickpea in the study areas. It is also expected that people living in the areas and any individual or organization who intend to invest and /or introduce new agricultural technologies in these areas will benefit from the generated data.

However, more detailed research and field experimentation are needed on $\mathrm{P}, \mathrm{S}, \mathrm{Zn}$ and $\mathrm{Cu}$ in the soils, as they are found to be deficient both in plants and soils. Additionally, determination of the soils' nutrient adsorbing capacities and residual release should be considered to develop a sound fertilizer recommendation.

\section{References}

Abayneh Esayas, Brehanu Debele (2006). Soil survey in Ethiopia. The past, present and future. pp. 61-79. Proceedings of the 7th Conference of the Ethiopian Society of Soil Science on Soils for Sustainable Development, April, 27-28, Addis Ababa, Ethiopia.

Ahlawat, I.P.S. and R.P. Sharma, 1996. Response of haricot bean genotypes to soil moisture regimes and phosphate fertilization. Indian Journal of Agronomy, 34: 70-74.

Ali, M., A.N. Ganeshamurthy and Ch. Srinivasarao, 2002. Role of nutrient management in pulse production. Fertilizer News 47: 83-90.

Asgelil Dibabe, Taye Bekele and Yesuf Assen. 2007. The status of micro-nutrient in Nitisols, Vertisols, Cambisols and Fluvisols in major maize, wheat, teff and citrus growing areas of Ethiopia. pp. 28-39. Proceedings of the Workshop on Status of Micro-nutrients in Ethiopia, December-27, 2007, Ethiopian Institute of Agricultural Research. Addis Ababa, Ethiopia.

Bhuiyan MAH, Khanam D Ali Y, (1999). Chickpea root nodulation and yield as affected by micronutrient application and Rhizobium inoculation. International Chickpea and Pigeonpea Newsletter 6:28-29.

Bouyoucos GH (1962). A recalibration of the hydrometer method for making mechanical analysis of soils. Agronomy Journal 43:434-438

Brady NC, Weil RR (2002). The Nature and Properties of Soils. $13^{\text {th }}$ ed. Pearson Education, Inc. Upper Saddle River, New Jersey pp 445-450. 
Bremner JM, Mulvaney CS (1982). Nitrogen. pp. 595-624. In: A.L Page (ed.). Methods of Soil Analysis, Part 2 , Chemical and Microbiological Properties. $2^{\text {nd }}$ ed. American Society of Agronomy, Madison, Wisconsin.

Cabrera, C., F. Lloris, R. Gimenez, M. Olalla, and C.M. Lo'pez, 2003. Mineral content in legumes and nuts: contribution to the Spanish dietary intake. The Science of the Total Environment 308: 1-14.

Din, J., A. Rashid and J. Ahmed, 1999. Diagnosis and correction of phosphorus deficiency in chickpea grown in rainfed calcareous soils of Pakistan. Journal of Indian Society of Soil Science 47: 504-509.

Eyassu Elias (2004). Nutrient flow analysis: A case study from southern Ethiopia. Ethiopian Journal of Natural Resource 6: 1-23.

FAO (2003). Scaling soil nutrient balances, J.P. Lesschen, R.D. Asiamah, P. Gicheru, S. Kanté, J.J. Stoorvogel \& Smaling, E.M.A. Rome.

Fisseha Itana (1992). Macro and micronutrients distribution in Ethiopian Vertisols landscapes. A Ph.D. Dissertation submitted to Institute fur Bondenkunde und Standortslehre, University of Hohenheim, Germany. $201 p$.

Fitter, A.H., 1974. A relationship between phosphorus requirement, immobilization of added phosphate and phosphate buffering capacity of Collier Shales. Journal of Soil Science 25: 41-50.

Fox RL, Kamprath EJ (1970). Phosphate sorption isotherms for evaluating the phosphate requirements of soils. Soil Science Society of America Proc. 34:902-907.

George T, Ladha KJ, Buresh JR, Garrity PD (1992). Managing native and legume fixed nitrogen in lowland ricebased cropping systems. Plant and Soil 141: 69-91.

Havlin, JL, Beaton JD, Tisdale SL, Nelson WL (1999). Soil Fertility and Fertilizers, An Introduction to Nutrient Management, $7^{\text {th }}$ ed, Pearson Education Institute, Singapore. $221 \mathrm{p}$.

Havlin, J.L., J.D. Beaton, S.L. Tisdale and W.L. Nelson, 2007. Soil Fertility and Fertilizers, An Introduction to Nutrient Management, $7^{\text {th }}$ ed, Pearson Education Institute, Singapore. $221 \mathrm{p}$.

Hunter AH (1980). Laboratory and Greenhouse Techniques for Nutrient Survey to Determine the Soil Amendments Required for Optimum Plant Growth. Agro Service International, Florida. pp 51-73.

Hussain, K., 2010. Sulfur and rhizobacteria application for enhancing nitrogen fixation in soybean. An MSc Thesis Presented to Arid Agriculture University, Rawalpindi, Pakistan.

Islam, M., S. Ali and R. Hayat, 2009. Effect of integrated application of phosphorus and sulphur on yield and micronutrient uptake by chickpea (Cicer arietinum L.). International Journal of Agriculture and Biology 11(1): 33-38.

Johnson GV, Fixen PE (1990). Testing Soils for Sulfur, Boron, Molydenum and Chlorine. pp. 265-273. In: R.L. Westerman (ed). Soil Testing and Plant Analysis SSSA, Inc. Madison, Wisconsin, USA.

Khan, H.R., K.G. McDonald and Z. Rengel, 1998a. Assessment of the Zn status of chickpea by plant analysis. Plant and Soil 198: 1-9.

Khan, H.R., K.G. McDonald and Z. Rengel, 1998b. Chickpea genotypes differ in their sensitivity to Zn deficiency. Plant and Soil 198: 11-18.

Khorgamy, A and A. Farnia, 2009. Effect of phosphorus and zinc fertilization on yield and yield components of chickpea cultivars. pp. 205-208. Proceedings, Vol. 9. African Crop Science Conference.

Landon, J.R., 1991. Booker Tropical Soil Manual. A Handbook of Soil Survey and Agricultural Land Evaluation in the Tropics and Sub-Tropics. 1st Edn., Longman, London, ISBN-13: 978-0582005570, 185p.

Lifang, H., S. Fan, Z. Zongsheng and F. Libo, 2000. A systematic approach to balancing soil nutrients in broad bean-rice rotation in Yunnan. Better Crops Int., 14: 18-23.

Lindsay WL, Norvell WA (1978). Development of a DTPA soil test for zinc, iron, manganese and copper. Soil Science Society of American Journal 42: 421-428.

Majid Mahmood Tahir, Kaleem Abbasi M, Nasir Rahim, Abdul Khaliq, Mushtaq Hussain Kazmi (2009). Effect of Rhizobium inoculation and NP fertilization on growth, yield and nodulation of soybean (Glycine max L.) in the sub-humid hilly region of major pulse growing regions of India. Commun. Soil Science and Plant Analysis 35: 2757-2769.

Marschner, H. 1995. Mineral Nutrition of Higher Plants 2 nd ed. Academic Press, London.

Mengel K, Kirkby AE ( 1987). Principles of Plant Nutrition. $4^{\text {th }}$ ed. International Potash Institute, Bern, Switzerland.

Misra, S.K., R.M. Upadhyay and V.N. Tiwari, 2002. Effect of salt and zinc on nodulation leghaemoglobin and nitrogen content of rabi legumes. Indian Journal of Pulses Research 15: 145-148.

Nagendra, T., V. Rao, P. Murugappan, R. Malarvizhi, M. Latha, T. Balaji and N. Prakashmany, 2007. Optimising crop nutrient needs using a systematic approach to soil fertility evaluation and improvement. Better Crops India pp 20-21.

Nelso DW, Sommers LE (1973). Deterination of total N in plant material. Agronomy Journal 65: 109-112.

nitrogen content of rabi legumes. Indian Journal of Pulses Research 15: 145-148.

Olivera, M., N. Tejera, C. Iribarne, A. Ocana and C. Lluch, 2004. Growth, nitrogen fixation and ammonium 
assimilation in haricot bean (Phaseolus vulgaris L.). Effect of phosphorus. Physiologia Plantarum, 121: 498505.

Olsen SR, Sommers LE (1982). Phosphorus. In: Methods of Soil Analysis. Part 2: Chemical and Microbial Properties, A.G. Page, R.H. Miller and D.R. Keeney (eds.). American Society of Agronomy, Madison, WI., USA., pp 403-430.

Portch S, Hunter A (2002). Special Publication No. 5, PPI/PPIC China Program. pp 1-62.

Rehm, G and M. Schmitt, 2002. Potassium for crop production. University of Minnesota Extension. http://www.extension.umn.edu/distribution/cropsystems/DC6794.html.

Sahlemedhin Sertsu, Ahmed Ali, (1983). Phosphorus sorption characteristics of some soils of Ethiopia. Ethiopian Journal of Agricultural Sciences 5: 1-12.

Sanchez PA, Sheperd KD, Soule MF, Place JR, Buresh AM, Izac N, Mokwunye AU, Kwesiga FR, Ndiritu CG, P.L. Woomer (1997). Soil Fertility Replenishment in Africa. An Investment in Natural Resources Capital. pp. 1-46. In: R.J. Buresh, P.A. Sanchez and F. Calnoun (eds.). SSSA Special Publication No. 51. SSSA. American Socity of Agronomy. Madison, Wisconsin, USA.

SAS, 1997. Statistical Analysis System Institute Inc., Cary. North Carolina. USA.

Scherer HW, Pacyna S, Manthey N, Schulz M ( 2006). Sulphur supply to peas (Pisum sativum L.) influence symbiotic nitrogen fixation. Plant Soil Environment 2: 72-77.

Sessitsch A, Howieson GJ, Perret X, Antoun H, Martinez-Romero E (2002). Advances in Rhizobium research. Critical Reviews in Plant Sciences 21: 323-378.

Sheleme Beyene, Sahlemedhin Sertsu, Kelsa Kena, Urage E., R. A.Mermut, W. D.Anderson J J. Schoenaeu and Fissaha Itanna, 2001. Low input sustainable agriculture in the Rift Valley, Ethiopia. pp. 236-243. Proceedings of the FAO/ISCW Expert Consultation on Management of Degraded Soils in Southern and East Africa MADS-SEA, 2nd Network Meeting. Sept. 18-22, Pretoria, South Africa.

Shiferaw Bekele, Richard Jones, Said Silim, Hailemariam Tekelewold, Eastonce Gwata (2007). Analysis of production costs, market opportunities and competitiveness of desi and kabuli chickpea in Ethiopia. IMPS(Improving productivity and market Success) of Ethiopian Farmers Project Working Paper 3. ILRI (International Livestock Research Institute), Nairobi, Kenya, 48 p.

Shrinivasarao CH, Ganeshamurthy AN, Ali M, Singh RN, Singh KK (2004). Sulphur fractions, distribution and their relationship with soil properties in different soil types of major pulse growing regions of India. Commun. Soil Science and Plant Analysis 35: 2757-2769.

Shu-Jie M, Yun-Fa Q,. Xiao-Zeng H, An M (2007). Nodule formation and development in soybean (Glycine max L.) in response to phosphorus supply in solution culture. Pedosphere 17(1): 36-43.

Sippola J, Ervio R (1977). Determination of boron in soils and plants by the azomethine-H method. Finnish Chemistry Letter pp 138 - 140.

Srinivasarao, C., N.A. Ganeshamurthy, A. Massod and N.R. Singh, 2006. Phosphorus and micronutrient nutrition of twenty chickpea genotypes on multi-nutrient deficient Typic Ustochrept. Journal of Plant Nutrition, 29: $747-763$

Srinivasarao,C., N.A. Ganeshamurthy and A. Massod, 2003. Nutritional constraints in pulses. Bulletin, Indian Institute of Pulses Research Kanpur, India, 34 p.

Tekalign Mamo, Haque I (1991). Phosphorus status of some Ethiopian soils. III. Evaluation of soil test methods for available phosphorus. Tropical Agriculture, 68(1): 51-56.

Tufemkci S. Somnez F, Sensoy RIG (2005). Effects of Arbuscular mycorrhiza fungus inoculation and phosphorus and nitrogen fertilization on some plant growth parameters and nutrient contents of chickpea. Journal of Biological Science 5: 738-743.

Van Reeuwijk (1993). Procedures for Soil Analysis. $4^{\text {th }}$ ed. International Soil Reference and Information Center, Netherlands, Technology Paper 9, 100p.

Waigel, G., 1986. The soils of Gununo area. Soil Conservation Research Project (SCRP). Research report 8, University of Berne, Switherland.

Wakene Negassa, Heluf Gebrekidan (2003). Forms of phosphorus and status of available micronutrients under different land-use systems of Alfisols in Bako area of Ethiopia. Ethiopian Journal of Natural Resources, 5(1):17-37.

Walkley A, Black IA (1934). An examination of the degtjareff method for determining soil organic matter and a proposed modification of the chromic acid titration method. Soil Science Society of America Journal 37: 2938.

Wolf B (1982). A comprehensive system of leaf analysis and its use for diagnosing crop nutrient status. Communication in Soil Science and Plant Analysis 13 (12): 1035-1059.

Wondimu Gebissa (2012). Physico-chemical properties of a Vertisols under different land use types in Taba watershed, Southern Ethiopia. An M.Sc. Thesis Presented to Hawassa University, Ethiopia, 17p.

Wondwosen Tena (2008). Identification of growth limiting nutrients in the major soil types of Kindo koye and 
Delbo atwaro Watershed Area, Wolaita Zone, Southern Ethiopia. In Awassa. An M.Sc. Thesis Presented to Hawassa University, Ethiopia, pp 36-71.

APPENDICES

Appendix Table 1. Inter-correlation coefficients (r) of number of nodules, nodule dry weight, plant height, dry matter yield, grain yield and nutrient concentration in shoot

\begin{tabular}{|c|c|c|c|c|c|c|c|c|c|c|c|c|c|c|c|}
\hline & $\begin{array}{l}\text { No. of } \\
\text { nodule }\end{array}$ & $\begin{array}{l}\text { Nodule } \\
\text { dry } \\
\text { weight }\end{array}$ & $\begin{array}{l}\text { Plant } \\
\text { height }\end{array}$ & $\begin{array}{l}\text { Dry } \\
\text { weight }\end{array}$ & $\begin{array}{l}\text { Grain } \\
\text { yield }\end{array}$ & $\mathrm{N}$ & $\mathrm{P}$ & K & $\mathrm{Ca}$ & $\mathrm{Mg}$ & S & $\mathrm{Fe}$ & $\mathrm{Mn}$ & $\mathrm{Zn}$ & $\mathrm{Cu}$ \\
\hline NNPP & 1.00 & & & & & & & & & & & & & & \\
\hline NDW & $0.85^{* * *}$ & 1.00 & & & & & & & & & & & & & \\
\hline $\mathrm{PH}$ & $0.49^{*}$ & $0.57^{*}$ & 1.00 & & & & & & & & & & & & \\
\hline DW & $0.82^{* * *}$ & $0.75^{* *}$ & $0.66^{* *}$ & 1.00 & & & & & & & & & & & \\
\hline GY & 0.39 & $0.49^{*}$ & $0.59^{* *}$ & $0.65^{* *}$ & 1.00 & & & & & & & & & & \\
\hline $\mathrm{N}$ & $0.44^{*}$ & $0.61^{* * *}$ & 0.35 & $0.54^{*}$ & $0.46^{*}$ & 1.00 & & & & & & & & & \\
\hline $\mathrm{P}$ & $0.81^{* * *}$ & $0.78^{* * *}$ & $0.73^{* * *}$ & $0.85^{* * *}$ & $0.63^{* *}$ & $0.43^{*}$ & 1.00 & & & & & & & & \\
\hline K & 0.30 & 0.31 & 0.28 & 0.36 & 0.39 & -0.01 & 0.39 & 1.00 & & & & & & & \\
\hline $\mathrm{Ca}$ & 0.13 & 0.11 & -0.37 & -0.04 & 0.11 & 0.21 & -0.08 & 0.10 & 1.00 & & & & & & \\
\hline $\mathrm{Mg}$ & $0.45^{*}$ & 0.31 & 0.16 & 0.40 & 0.22 & 0.23 & 0.42 & 0.28 & 0.16 & 1.00 & & & & & \\
\hline S & 0.28 & 0.15 & 0.26 & $0.47^{*}$ & $0.50^{*}$ & -0.03 & 0.33 & 0.23 & 0.01 & 0.01 & 1.00 & & & & \\
\hline $\mathrm{Fe}$ & -0.25 & -0.15 & 0.25 & -0.06 & 0.35 & -0.11 & 0.09 & 0.43 & -0.06 & -0.16 & 0.17 & 1.00 & & & \\
\hline $\mathrm{Mn}$ & 0.21 & 0.23 & 0.07 & -0.03 & -0.07 & 0.25 & 0.09 & 0.15 & 0.37 & $0.42^{*}$ & -0.26 & 0.21 & 1.00 & & \\
\hline $\mathrm{Zn}$ & $0.70^{* * *}$ & $0.63^{* *}$ & $0.53^{*}$ & $0.73^{* * *}$ & $0.44^{*}$ & $0.54^{*}$ & $0.74^{* * *}$ & 0.31 & -0.05 & $0.52^{*}$ & 0.21 & -0.10 & 0.11 & 1.00 & \\
\hline $\mathrm{Cu}$ & -0.11 & -0.14 & -0.11 & -0.08 & 0.07 & -0.29 & -0.08 & 0.67 & 0.22 & 0.06 & 0.03 & $0.52^{*}$ & 0.34 & -0.13 & 1.00 \\
\hline
\end{tabular}

Number of observations $(n) " 24 . * * *$ and $* * *$ indicate significance at $0.05,0.01$ and 0.001 levels, respectively.

Appendix Table 2. Inter-correlation coefficients (r) of number of nodules, nodule dry weight, plant height, dry matter yield, grain yield and nutrient uptake of shoot

\begin{tabular}{|c|c|c|c|c|c|c|c|c|c|c|c|c|c|c|c|}
\hline & $\begin{array}{l}\text { No. of } \\
\text { nodule }\end{array}$ & $\begin{array}{l}\text { Nodule } \\
\text { dry } \\
\text { weight }\end{array}$ & $\begin{array}{l}\text { Plant } \\
\text { height }\end{array}$ & $\begin{array}{l}\text { Dry } \\
\text { weight }\end{array}$ & $\begin{array}{l}\text { Grain } \\
\text { yield }\end{array}$ & $\mathrm{N}$ & $P$ & $\mathrm{~K}$ & $\mathrm{Ca}$ & $\mathrm{Mg}$ & $S$ & $\mathrm{Fe}$ & $\mathrm{Mn}$ & $\mathrm{Zn}$ & $\mathrm{Cu}$ \\
\hline NNPP & 1.00 & & & & & & & & & & & & & & \\
\hline NDW & $0.85^{* * *}$ & 1.00 & & & & & & & & & & & & & \\
\hline PH & $0.59^{*}$ & $0.57^{*}$ & 1.00 & & & & & & & & & & & & \\
\hline DW & $0.82^{* * *}$ & $0.74^{* * *}$ & $0.65^{* *}$ & 1.00 & & & & & & & & & & & \\
\hline GY & 0.38 & $0.49^{*}$ & $0.59^{* *}$ & $0.65^{* *}$ & 1.000 & & & & & & & & & & \\
\hline $\mathrm{N}$ & $0.71^{* * *}$ & $0.78^{* * *}$ & $0.60^{* *}$ & $0.91^{* * *}$ & $0.69^{* *}$ & 1.00 & & & & & & & & & \\
\hline P & $0.83^{* * *}$ & $0.77^{* * *}$ & $0.70^{* * *}$ & $0.96^{* * *}$ & $0.66^{* *}$ & $0.85^{* * *}$ & 1.00 & & & & & & & & \\
\hline $\mathrm{K}$ & $0.70^{* * *}$ & $0.66^{* *}$ & $0.55^{* *}$ & $0.87^{* * *}$ & $0.62^{* *}$ & $0.79^{* * *}$ & $0.84^{* * *}$ & 1.00 & & & & & & & \\
\hline $\mathrm{Ca}$ & $0.79^{* * *}$ & $0.68^{* *}$ & 0.31 & $0.79^{* * *}$ & $0.49^{*}$ & $0.76^{* * *}$ & $0.74^{3 * *}$ & $0.71^{* * *}$ & 1.00 & & & & & & \\
\hline $\mathrm{Mg}$ & $0.77^{* * *}$ & $0.65^{* *}$ & $0.53^{*}$ & $0.87^{* * *}$ & $0.57^{* *}$ & $0.80^{* * *}$ & $0.83^{3 * * *}$ & $0.83^{* * *}$ & $0.79^{* * *}$ & 1.00 & & & & & \\
\hline S & $0.58^{* *}$ & $0.45^{*}$ & $0.48^{*}$ & $0.80^{* * *}$ & $0.63^{* *}$ & $0.70^{* * * *}$ & $0.73^{* * *}$ & $0.63^{* *}$ & $0.59^{* *}$ & $0.61^{* *}$ & 1.00 & & & & \\
\hline $\mathrm{Fe}$ & 0.36 & 0.39 & $0.64^{* *}$ & $0.67^{* * *}$ & $0.69^{* * *}$ & $0.63^{* *}$ & $0.60^{* * *}$ & $0.76^{* * *}$ & 0.39 & $0.56^{*}$ & $0.64^{* *}$ & 1.00 & & & \\
\hline $\mathrm{Mn}$ & $0.82^{* * *}$ & $0.76^{* * *}$ & $0.60^{* *}$ & $0.85^{* * *}$ & $0.49^{*}$ & $0.78^{* * *}$ & $0.81^{* * * *}$ & $0.83^{* * *}$ & $0.75^{* * *}$ & $0.87^{* * * *}$ & $0.60^{* *}$ & $0.66^{* * *}$ & 1.00 & & \\
\hline $\mathrm{Zn}$ & $0.78^{* * *}$ & $0.69^{* * *}$ & $0.63^{* *}$ & $0.92^{* * *}$ & $0.59^{* *}$ & $0.86^{* * *}$ & $0.91^{* * *}$ & $0.82^{* * *}$ & $0.75^{* * *}$ & $0.85^{* * * *}$ & $0.71^{* * *}$ & $0.64^{* *}$ & $0.81^{* * *}$ & 1.00 & \\
\hline $\mathrm{Cu}$ & $0.50^{*}$ & $0.43^{*}$ & 0.36 & $0.65^{* *}$ & $0.47^{*}$ & $0.53^{*}$ & $0.62^{* *}$ & $0.85^{* * *}$ & $0.53^{* * *}$ & $0.62^{* * *}$ & $0.46^{*}$ & $0.74^{* * * *}$ & $0.73^{* * *}$ & $0.60^{* *}$ & 1.00 \\
\hline
\end{tabular}

Number of observations $(n) " 21 . * * *$ and $* * *$ indicate significance at $0.05,0.01$ and 0.001 levels, respectively 